\title{
Efficiency Research of the Beverage Based on the Still Mineral Water and BAD "Eramin"
}

\author{
Vitaliy O. Tolmachev ${ }^{1}$, Sergey L. Tikhonov ${ }^{1 *}$, Natalya V. Tikhonova'
}

${ }^{1}$ Ural State University of Economics, Ekaterinburg, Russian Federation, *e-mail: tihonov75@bk.ru

Keywords:

liquid consumption;

sports drink;

performance efficiency;

fatigue;

athletes;

enzymes

\begin{abstract}
The article presents analysis results of the actual consumption of drinking water and sport drinks by athletes before and after training and concerns the effectiveness study of the drink based on non-carbonated mineral drinking water "ARDVI" and dietary supplement "Eramin". Analysis of liquid consumption by sportspeople before and after training shows that all athletes participating in the experiment $(100,0 \%)$ consume bottled drinking water for dehydration. The maximum consumption of bottled water is $1500 \mathrm{ml}$, the minimum $150 \mathrm{ml}$; the amount of tea drunk by judoists equal $500 \mathrm{ml}$ with an average amount of $324 \mathrm{ml}$; carbonated drinks ("Coca-Cola", "Sprite", etc.) athletes do not use. The authors suggested judo athletes to replace $500 \mathrm{ml}$ of bottled water with $500 \mathrm{ml}$ of a drink based on the mineral water "ARDVI" and the biologically active supplement "Eramin". According to the results of preclinical research conducted on rats, the introduction of this drink to animals through a probe contributes to the muscle and epithelial tissues regeneration. When studying the testosterone and cortisol amount in the blood of athletes, authors found that on the 90th day of taking a drink based on mineral water "ARDVI" these indicators were $84.2 \pm 0.6$ and $35.1 \pm 0.8 \mathrm{nmol} / \mathrm{l}$, respectively; and in the first group $-71.3 \pm 0.5$ and $26.4 \pm 0.4 \mathrm{nmol} / \mathrm{l}$, which is 18.1 and $33.0 \%$ higher than in the control group. An increase in the number of studied hormones in the blood of athletes can indicate an increase in physical performance and a decrease in fatigue. Researchers noted a high value of the creatine phosphokinase enzyme (137 units/l) in the blood serum of athletes in the control group, which indicates training intensity and the possibility of muscle tissue injury. In the blood of athletes of the experimental group, the amount of this enzyme is 85 units/l, which is lower than the control by $62.0 \%$. There was a significant decrease in the activity of AST and ALT enzymes by 15.8 and $22.0 \%$ while consuming studied drink by athletes. At the same time, the muscle injury index corresponded to the norm. Athletes who took the sports drink under study had the optimal value of the de Ritis coefficient (1.33). Authors concluded that the athletes use of drink based on mineral water "ARDVI" and dietary supplement "Eramin" allows sportsmen to maintain performance, reduce fatigue and prevent muscle tissue damage, including the myocardium.
\end{abstract}

\section{Исследование эффективности напитка на основе негазированной минеральной Питьевой воды и БАД «Эрамин»}

\author{
В.О. Толмачев ${ }^{1}$, С.Л. Тихонов ${ }^{1 *}$, Н.В. Тихонова ${ }^{1}$
}

'Уральский государственный экономический университет, г. Екатеринбург, Российская Федерация, *e-таil: tihonov75@bk.ги 


Ключевые слова:
потребление
жидости;
спортивный напиток;
работоспособность;
утомляемость;
спортсмены;
ферменты

Для цитирования: Толмачев В.О., Тихонов С.Л., Тихонова Н.В. Исследование эффективности напитка на основе негазированной минеральной питьевой воды и БАД «Эрамин» // Индустрия пuтания|Food Industry. 2020. T. 5, № 3. C. 17-24. DOI: 10.29141/25001922-2020-5-3-2

Дата поступления статьи: 4 мая 2020 г.

\begin{abstract}
Реферат
В статье представлены результаты анализа фактического потребления питьевой воды и спортивных напитков спортсменами перед и после тренировки и исследования эффективности напитка на основе негазированной минеральной питьевой воды «АРДВИ» и биологически активной добавки «Эрамин». Анализ потребления жидкости спортсменами по видам спорта перед и после тренировки свидетельствуют о том, что для дегидратации все спортсмены - участники эксперимента (100,0 \%) - употребляют бутилированную питьевую воду. Максимальное потребление бутилированной воды составляет 1500 мл, минимальное - 150 мл; количество выпитого чая дзюдоистами - на уровне 500 мл при среднем показателе 324 мл; газированные напитки («Кока-Кола», «Спрайт» и др.) спортсмены не употребляли. Спортсменам-дзюдоистам было предложено заменить 500 мл бутиллированной воды на 500 мл напитка на основе минеральной воды «АРДВИ» и биологически активной добавки «Эрамин». По результатам доклинических исследований, проведенных на крысах, установлено, что введение животным через зонд указанного напитка способствует регенерации мышечной и эпителиальной тканей. При исследовании содержания тестостерона и кортизола в крови спортсменов было выявлено, что на 90-е сутки приема напитка на основе минеральной воды «АРДВИ» эти показатели составили 84,2 $\pm 0,6$ и 35,1 \pm 0,8 нмоль/л

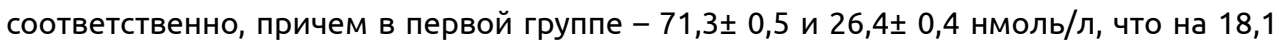
и 33,0 \% выше, чем в контрольной. Увеличение количества исследуемых гормонов в крови спортсменов позволяет свидетельствовать о повышении физической работоспособности и снижении утомляемости. В сыворотке крови спортсменов контрольной группы отмечено высокое содержание фермента креатинфосфокиназы (137 ед./л), что свидетельствует об интенсивности тренировок и возможности травмирования мышечной ткани. В крови спортсменов опытной группы количество указанного фермента составляет 85 ед./л, что ниже контроля на 62,0\%. Отмечено достоверное снижение активности ферментов АСТ и АЛт на 15,8 и 22,0\% на фоне употребления исследуемого напитка спортсменами. При этом индекс травмирования мышц соответствовал норме. У спортсменов, принимавших исследуемый спортивный напиток, коэффициент де Ритиса был оптимальным и составил 1,33. Сделан вывод: употребление спортсменами напитка на основе минеральной воды «АРДВИ» и биологически активной добавки «Эрамин» позволяет сохранять работоспособность, снизить утомляемость и предупредить повреждения мышечной ткани, в том числе миокарда.
\end{abstract}

дата поступления статьи. 4 мая 2020 г.

\section{Relevance}

During physical training, athletes have a general decrease in water amount in the body with hemoconcentration (so-called dehydration), which can have adverse consequences, in particular, a decrease in the training and physical indicators effectiveness and increased fatigue [1]. Dehydration leads to the significant index deterioration of speed and strength qualities and physical strength in both aerobic and anaerobic energy processes [2; 3; 4]. Physical activity leads to a decrease in body weight. To restore fluid status, scientists recommend to consume 1.5 liters of liquid per $1 \mathrm{~kg}$ of lost weight $[5 ; 6]$. Fluid losses are high during physical training. If the recovery period between physical activities is less than 12 hours, then athletes need to ensure sufficient fluid intake into the body. At the same time, they have to considering that excess fluid, as well as its lack, negatively affects physical performance $[7 ; 8]$. Excessive fluid intake can cause discomfort in the digestive system and, consequently, weaken physical performance $[9 ; 10]$. However, there is a positive aspect of excessive fluid intake by athletes, in particular, large volumes of fluid in the stomach enhance the rehydration process [11]. From the above, determining the optimal amount of fluid intake by athletes is important for maintaining, restoring physical performance and achieving high training and competitive results.

During intensive training along with the fluid loss by the athlete body, there are losses of mineral substances. The need for biologically active substances increases. 
Many biologically active drugs that help restore performance are in the list of prohibited for use by athletes. In this regard, the development and effectiveness evaluation of the new complex drug, including sports drinks that restore water and mineral balance in the body of an athlete, is an urgent task of modern nutritional science. Plant extracts that have a "soft" effect on the adaptive capabilities of athletes deserve special attention as a source of biologically active substances [12].

One of the well-known and effective herbal remedies is "Erakond". This is alfalfa extract, enriched with ten microelements. Sports results of athletes confirmed the effectiveness of its application (the speedskaters under the leadership of the Honored coach of the USSR, Master of sports Boris F. Vashlyaev). Researchers tested "Erakond" during the training period of speedskaters on the eve of the XVII winter Olympic games in Lillehammer (Norway, 1994). Russian skaters took "Erakond" after each training session in the amount of one pill. They did not use other pharmacological agents. The training took place on flat terrain, in the conditions of the middle mountains (Almaty, Medeo, Kazakhstan, height - 1700 m; Davos, Switzerland, height - $1500 \mathrm{~m}$ above sea level). Athletes and coaches during the training process noted high performance and rapid recovery; they did not observe adverse acclimatization issues in the mountains with subsequent acclimatization. Russian highly qualified athletes - masters of sports of international class and masters of sports achieved significant results in high-level competitions: the Olympic games, world and European Championships, World Cup series and international competitions in athletics and speed skating. At the same time, athletes who took dietary supplements were under constant control of the anti-doping laboratory of the Russian Federation.

Together with LLC Research and Production Enterprise "Erakond-Ural" (Ekaterinburg) the authors developed an improved analogue of "Erakond" a biologically active additive "Eramin".

During training and competitions athletes often injure attachments and joints; they often have a syndrome of delayed onset muscle soreness (DOMS) which appears two or three days after exercise. To prevent DOMS, the athlete diet must include an essential element silicon, that increases the attachments elasticity [13]. The action mechanism of silicon is to enhance the enzyme pepsidilum hydroxilase, converting a proline to hydroxyproline. Oxyproline is part of the collagen fibers, and provides elasticity of the attachments, and prevents their breaks [14]. Scientists proved that in cases of injuries to muscle tissue and attachments, the amount of silicon in the places of bursting and breakage increased by more than 100 times, and its concentration in the blood of an athlete decreased by $5-7$ times [15].

The recommended rate of silicon consumption by the Federal center for hygiene and epidemiology of Rospotrebnadzor is $30 \mathrm{mg} / \mathrm{day}^{1}$. Silicon does not have a cumulative effect and is quickly removed from the body [16]. Together with LLC "Niagara" (Chelyabinsk), the authors developed a sports drink enriched with dietary supplements "Eramin" based on non-carbonated drinking mineral water "ARDVI", containing natural metasilicic acid in a physiologically significant dose of $24.7-69.0 \mathrm{mg} / \mathrm{dm}^{3}$.

The aim of the work is to study the effectiveness of a drink based on non-carbonated mineral drinking water "ARDVI" and dietary additive "Eramin" by partially replacing drinking bottled water in the diet of athletes.

\section{Objects and Methods of the Research}

The authors run the research on the sports club basis of the Physical Education and Sports Department of the South Ural State Agrarian University (Troitsk, Chelyabinsk region).

They determined the liquid amount consumed by athletes in different sports using the daily nutrition method, including the consumption of various types of liquids and beverages, according to officially approved Guidelines ${ }^{2}$. To assess the consumption of drinking bottled water and drinks by highly qualified judoists, the researchers developed a questionnaire with questions on all types of liquids and beverages that athletes drunk before and after training. The group of judoists included 20 masters, candidates for master of sports and first-class athletes with the following training regime: 1 time a day for 3 hours, 6 training sessions a week.

A man chose white Wistar rats in the vivarium of the Veterinary Medicine Institute of the South Ural State University (Chelyabinsk) to study the regenerating ability of the drink based on still drinking water "ARDVI" and dietary additive "Eramin". For the experiment, the researchers formed three groups of animals: the first group was a control one - the rats received the main diet; the second group received $25 \mathrm{ml}$ of isotonic sodium chloride solution orally in addition to the general animal diet; the third group received a drink based on non-carbonated mineral drinking water and dietary additive "Eramin" in an amount of $25 \mathrm{ml}$. One introduced isotonic solution

\footnotetext{
${ }^{1}$ Norms of Physiological Needs in Energy and Food Substances for Various Groups of the Population of the Russian Federation. Methodological Recommendations. Moscow: Federal Center for Hygiene and Epidemiology of Rospotrebnadzor. 2009. 36 p.

${ }^{2}$ Methodological Recommendations for Assessing the Amount of Food Consumed by the Method of 24-Hour (Daily) Reproduction of Nutrition / app. Deputy Chief State Sanitary Doctor of the Russian Federation. Decree No. C1-19/14-17. February 26, 1996.
} 
and drink into the body of laboratory animals for 30 days before applying the sword cut and 15 days after (the healing period). A sword cut was 15*15 $\mathrm{mm}$ applied with a scalpel to study the drink effect on the regenerating ability of tissues. The animals were under anesthesia. The researchers evaluated wound healing process by calculating its area.

A man measured adaptive capabilities of athletes by the amount of cortisol and testosterone hormones, aspartate aminotransferase (AST), alanine aminotransferase (ALT) and creatine kinase (creatine phosphokinase) in the blood; determined indicators in the interdepartmental laboratory of the Veterinary Medicine Institute of the South Ural State University. They specified cortisol and testosterone amount by enzyme immunoassay using a set of ready-made reagents "Cortisol EIA 01" and "Testosterone 96"; creatine kinase-kinetic - by the immunobiological method using a set of ready-made reagents, alanine and aspartate aminotransferase - on the analyzer "Labsystems".

For the experiment, there were 2 groups of judoists: the first group - control one, athletes consumed liquid and drinks without changes; the second group - experienced, athletes replaced 500 $\mathrm{ml}$ of drinking water for $500 \mathrm{ml}$ of a drink based on still drinking water "ARDVI" and dietary additive "Eramin", which they took daily for 90 days after training. The computer program Statistica 9 performed statistical data processing.

\section{Results and Its Discussion}

Table 1 shows data on the consumption of drinking bottled water and beverages by highly qualified judoists before and after training. During the study the researchers used an informative indicator of athlete liquid consumption named the "Mode of Consumption Values" that means the most frequent (preferred) volume of fluid body consumed by individuals.

The studied indicator also provides information about the liquid consumption per person.

The analysis results of the liquid consumption before training indicate that all athletes $(100.0 \%)$ consumed bottled water. The maximum consumption of bottled water is $1,500 \mathrm{ml}$, and the minimum is $150 \mathrm{ml}$. Tea gains the second place in terms of the amount of liquid consumed by athletes before training. Thus, the maximum amount of tea consumed by judoists is at the level of $500 \mathrm{ml}$ with an average consumption of $324 \mathrm{ml}$. Only $40.0 \%$ of combat athletes consume sports drinks before training. The athletes did not use carbonated drinks (Coca-Cola, Sprite, etc.).

The greatest number of athletes (100.0\%) preferred drinking water after training. The average consumption of bottled water by judoists after training is $1,247 \mathrm{ml} .80 .0 \%$ judoists consume sports drinks. An average value for sports drinks in each group of athletes is $547 \mathrm{ml}$. The obtained data indicate that bottled drinking water, followed by tea is the main liquid for rehydration after training.

The analysis of the "Mode of Consumption Values" demonstrates that judoists mostly consume water, tea, sports drinks, coffee and juices in volumes of $500,200,300,100$ and $150 \mathrm{ml}$, respectively.

The researchers suggested judoists to replace 500 $\mathrm{ml}$ of bottled water with $500 \mathrm{ml}$ of a drink based on still water "ARDVI" and dietary additive "Eramin". It contains the following prescription ingredients: hibiscus extract; dietary additive "Eramin"; stevioside; potassium sorbate; sodium benzoate; natural mineral drinking water "ARDVI".

Table 1. Consumption of Drinking Bottled Water and Drinks by Highly Qualified Judoists Before and After Training, $\mathrm{ml}$ Таблица 1. Потребление питьевой бутилированной воды и напитков высококвалифицированными спортсменами-дзюдоистами до и после тренировки, мл

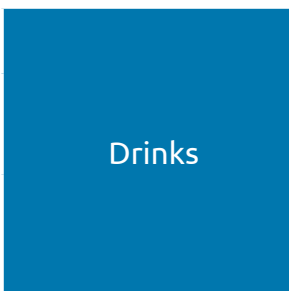

Drinking Bottled Water

Sports Drinks

Tea

Coffee

Juices, Nectar

Coca-Cola, Sprite and Another Sweet Carbonated Drinks

\begin{tabular}{|c|c|c|c|c|c|c|c|c|c|c|c|}
\hline \multicolumn{12}{|c|}{ Consumption } \\
\hline \multicolumn{2}{|c|}{ Average } & \multicolumn{2}{|c|}{ Mode } & \multicolumn{2}{|c|}{ Minimum } & \multicolumn{2}{|c|}{ Maximum } & \multicolumn{2}{|c|}{$\begin{array}{c}\text { Consumers } \\
\text { Number }\end{array}$} & \multicolumn{2}{|c|}{$\begin{array}{c}\text { Consumers } \\
\text { Proportion, \% }\end{array}$} \\
\hline 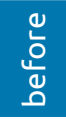 & 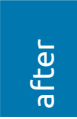 & 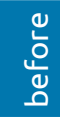 & $\frac{5}{\frac{1}{0}}$ & 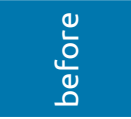 & 离 & 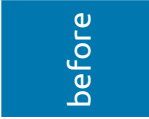 & 迹 & 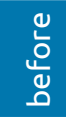 & $\underset{\frac{d}{0}}{\frac{1}{0}}$ & 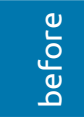 & 迹 \\
\hline 298 & 1247 & 500 & 500 & $150 \pm 27$ & $300 \pm 23$ & $1500 \pm 46$ & $2000 \pm 51$ & 20 & 20 & 100 & 100 \\
\hline 120 & 547 & 100 & 300 & $50 \pm 12$ & $200 \pm 23$ & $200 \pm 29$ & $1000 \pm 18$ & 8 & 16 & 40 & 80 \\
\hline 324 & 228 & 150 & 200 & $100 \pm 18$ & $150 \pm 19$ & $500 \pm 31$ & $500 \pm 24$ & 14 & 16 & 70 & 80 \\
\hline 64 & 89 & 100 & 100 & $50 \pm 11$ & $50 \pm 8$ & $250 \pm 26$ & $150 \pm 32$ & 8 & 6 & 40 & 30 \\
\hline 289 & 158 & 250 & 150 & $150 \pm 23$ & $100 \pm 14$ & $500 \pm 28$ & $250 \pm 17$ & 16 & 8 & 80 & 40 \\
\hline
\end{tabular}

Did Not Consume 
The table 2 shows the regulated indicators of soft drinks based on mineral water "ARDVI" and dietary additive "Eramin".

Consumption of the recommended amount of the drink $(500 \mathrm{ml})$ provides athletes from 10.0 to $60.0 \%$ of the body's needs in trace elements and bioflavonoids.

According to preliminary preclinical studies on the muscle and epithelial tissue regeneration conducted on white rats to establish the drink use possibility for preventing ligament injuries and improve the muscle tissue tears healing in athletes, authors found that the drink introduction into the test animals through the probe promoted wound healing. So, after 5,10 and 14 days, the area of the wound surface was less by $25.0 ; 36.0$ and $72.0 \%$ compared to the control group of laboratory animals.

Testosterone and cortisol concentration are to reflect the adaptive capabilities of the athlete body to the training process and the level of performance recovery [17]. When studying the content of testosterone and cortisol in the athlete blood of the sec- ond group on the 90th day of taking a drink based on still mineral water "ARDVI" was $84.2 \pm 0.6$ and $35.1 \pm 0.8 \mathrm{nmol} / \mathrm{l}$, in the first $-71.3 \pm 0.5$ and 26.4 $\pm 0.4 \mathrm{nmol} / \mathrm{l}$, respectively, which is 18.1 and $33.0 \%$ higher than in the control group. An increase in the testosterone and cortisol amount in the blood indicates an increase in physical performance and a decrease in fatigue.

Thus, replacing $500 \mathrm{ml}$ of drinking water daily for 90 days in the diet of judoists with a drink based on mineral water "ARDVI" and dietary additive "Eramin" increases performance and reduces fatigue.

The study of physiological state biomarkers, fitness and adaptive capabilities (enzymes released into the blood when the protective ability of the myocyte membrane is violated during high physical exertion) are of particular importance. Information about changes in the enzymes activity during the training cycle allows to calculate the optimal level of physical activity for each athlete and the recovery process direction of his body. Table 3 shows the activity of aspartate aminotransferase (AST), alanine

Table 2. Regulated Indicators of Soft Drinks

Based on Mineral Water "ARDVI" and Dietary Additive "Eramin" in a Polymer Container with a Capacity of $0.5 \mathrm{dm}^{3}$ Таблица 2. Регламентируемые показатели безалкогольного напитка на основе минеральной воды «АРДВИ» и БАД «Эрамин» в полимерной таре вместимостью 0,5 дм

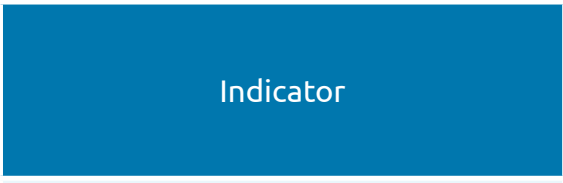

Appearance

Color

Taste

Aroma

Basic Ionic Composition, mg / l : $\mathrm{HCO}_{3}$

$\mathrm{SO}_{4}{ }^{2-}$

$\mathrm{Cl}^{-}$

$\mathrm{Ca}^{2+}$

$\mathrm{Mg}^{2+}$

$(\mathrm{Na}+\mathrm{K})^{+}$

Mineralization, $\mathrm{g} / \mathrm{dm}^{3}$

Specific Component $\mathrm{H}_{2} \mathrm{SiO}_{3}, \mathrm{mg} / \mathrm{dm}^{3}$

Bio-Flavonoids in Terms

of Luteolin-7-Glucoside, $\mathrm{mg} / 0.5 \mathrm{dm}^{3}$

Microelements, $\mathrm{mg} / 0.5 \mathrm{dm}^{3}$

Iron

Zinc

Copper

Manganese

Cobalt

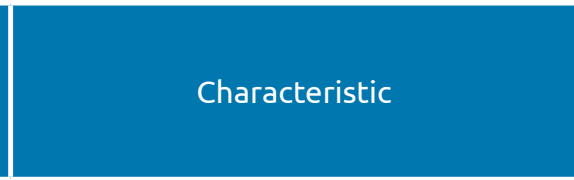

Opaque Liquid

Brown, Relevant to the Color of the Raw Material Used

Herbaceous, Typical to Alfalfa

Aroma of Herbs. Foreign Taste and Smell are not Allowed

$$
\begin{gathered}
384-420 \\
85-90 \\
110-120 \\
90-96 \\
78-90 \\
70-80 \\
0.7-0.9 \\
24.7-69.0
\end{gathered}
$$$$
\text { 130-180 }
$$

Rate of Daily Requirements when Consumed $500 \mathrm{ml}$ with an Average Amount of a Physiologically Significant Substance, \% 
Table 3. Enzymatic Blood Activity of Highly Qualified Judoists, units/l $(M \pm m ; n=20)$

Таблица 3. Ферментативная активность крови высококвалифицированных спортсменов-дзюдоистов, ед./л $(M \pm m ; n=20)$

\begin{tabular}{|l|c|c|c|}
\multicolumn{1}{c|}{ Enzyme } & & \multicolumn{2}{c|}{ Group of Athletes } \\
\hline Aspartate Aminotransferase (AST) & Reference Interval, Norm & Control & Experimental \\
\hline Alanine Aminotransferase (ALT) & $0-31$ & $10.1 \pm 0.2$ & $8.5 \pm 0.2^{*}$ \\
\hline Creatine Phosphokinase (CPK) & $0-34$ & $8.2 \pm 0.1$ & $6.4 \pm 0.1^{*}$ \\
\hline De Ritis Coefficient (AST/ALT) & $0-145$ & $137 \pm 4$ & $85 \pm 3$ \\
\hline CPK/ALT & 1.33 & 1.23 & 1.33 \\
\hline
\end{tabular}

Note. *Reliably when $\mathrm{P} \leq 0,01$.

aminotransferase (ALT) and creatine phosphokinase (CPK) in the blood serum of athletes (table 3).

In the blood serum of the athletes in the control group there is a high CPK value (137 units/l), indicating the training intensity, the possibility to injure the muscle tissue and being consistent with the research results [18]. The authors assume that the cellular enzymes release in blood associates with the free radicals formation and, consequently, with changes in the permeability of the cell membrane, while in blood serum of sportsmen of the experimental group CPK is 85 units/l, which is below the benchmark by $62.0 \%$.

The study of the cellular transaminases (AST and ALT enzymes) activity plays crucial role. There was a significant decrease in their activity by 15.8 and $22.0 \%$ in the second group of athletes compared to the control. At the same time, the ratio of CPK/ AST, or index of muscle injury, in the control group was at the level of 13 units and above the norm by 3 units. An important diagnostic value of the cardiovascular system state is the ratio of AST/ALT (de Ritis coefficient). In the experimental group, it was optimal and consisted of 1.33 , while in the control group it was 1.34. The obtained data indicates the initial stage of myocardial damage in athletes of the control group.

\section{Conclusion}

Authors, based on the conducted research, found that all highly qualified athletes used drinking water before and after training for rehydration. Judoists consumed the maximum amount of water, and weightlifters - the minimum. In clinical studies, judoists replaced $500 \mathrm{ml}$ of bottled drinking water with $500 \mathrm{ml}$ of a drink based on mineral water "ARDVI" and dietary additive "Eramin".

When conducting preclinical studies on white rats, he researchers established the positive effect of the drink on the soft tissue regeneration by its introduction into laboratory animals with a wound surface. The results obtained suggest that the drink under study will enhance the athlete recovery and prevent injury to muscle tissue, including the myocardium. The results of preclinical studies are consistent with the muscle injury index and the de Ritis coefficient.

Thus, in the control group of athletes, the injury index was higher than the norm, and against the background of consuming the drink it corresponded to the standard value and was lower than the control by $30.0 \%$. The de Ritis coefficient indicated the initial stage of myocardial damage in the control group of athletes.

According to the experiment results, the use of the studied drink increases the adaptive capabilities of the body, as evidenced by an increase in the testosterone and cortisol content in the blood of athletes of the experimental group; this is consistent with the content of metabolic biomarkers (CPK, AST, ALT) in this group and indicates an increase in the athlete adaptation to increased physical activity, reduced fatigue, and increased creatine phosphokinase mechanism of energy supply. The authors connect the increased amount of the studied biomarkers in athletes of the control group with an increase in the enzymes release into the blood under the influence of physical activity. The increase in the activity of these enzymes has a different etiology, but can be due to mechanical injury of the skeletal muscles caused by intense physical activity and the development of oxidant metabolic stress caused by the free radical occurrence during training. Also, a significant increase in the content of these enzymes in the blood of athletes in the control group is a marker of overtraining and weakening of the recovery process. 


\section{Bibliography}

1. Kolesnikova, A.A.; Artemjeva, N.K.; Tarasenko, A.A. Dinamika Elektrolitnogo Statusa Velosipedistov Vysokoj Kvalifikacii na Fone Priema Regidratacionnogo Napitka Funkcional'nogo Naznacheniya [Electrolyte Status Dynamics of Highly Qualified Cyclists Against the Background of Receiving a Rehydration Drink of Functional Purpose]. Fizicheskaya kultura, sport - nauka i praktika. 2016. № 4. Pp. $73-78$.

2. Savoie, F.-A.; Kenefick, R.W.; Ely, B.R.; Cheuvront, S.N.; Goulet, E.D.B. Effect of Hypohydration on Muscle Endurance, Strength, Anaerobic Power and Capacity and Vertical Jumping Ability: a Metaanalysis. Sports Med. (Auckland, NZ). 2015. Vol. 45, iss. 8. Pp. 1207-1227. DOI: 10.1007/s4027901503490.

3. McCartney, D.; Desbrow, B.; Irwin, C. The Effect of Fluid Intake Following Dehydration on Subsequent Athletic and Cognitive Performance: a Systematic Review and Metaanalysis. Sports Medicine Open. 2017. Vol. 3, iss. 1. P. 13. DOI: 10.1186/s407980170079y.

4. Sawka, M.N.; Burke, L.M.; Eichner, E.R.; Maughan, R.J.; Montain, S.J. American College of Sports Medicine Position Stand. Exercise and Fluid Replacement. Medicine and Science in Sports and Exercise. 2007. Vol. 39, iss. 2. Pp. 377-390. D0I: 10.1249/mss.0b013e31802ca597.

5. Thomas, D.T.; Erdman, K.A.; Burke, L.M. Position of the Academy of Nutrition and Dietetics, Dietitians of Canada, and the American College of Sports Medicine: Nutrition and Athletic Performance. Journal of the Academy of Nutrition and Dietetics. 2016. Vol. 116 iss. 3. Pp. 501-528. DOI: 10.1016/j.jand.2015.12.006.

6. McDermott, B.P.; Anderson, S.A.; Armstrong, L.E.; Casa, D.J.; Cheuvront, S.N.; Cooper, L., et al. National Athletic Trainers' Association Position Statement: Fluid Replacement for the Physically Active. Journal of Athletic Training. 2017. Vol. 52, iss. 9. Pp. 877-895. D0l: 10.4085/1062-6050-52.9.02.

7. Kurashvili, V.A. Problema Gidratacii u Elitnyh Sportsmenov [Hydration Problem in Elite Athletes]. Sportivnaya Medicina: Nauka i Prak tika. 2015. № 1. Pp. 14-21.

8. Maughan, R.J.; Shirreffs, S.M. Dehydration and Rehydration in Competitive Sport. Scandinavian Journal of Medicine and Science in Sports. 2010. Vol. 20, iss. 11, sup. 3. Pp. 40-47. DOI: 10.1111/j.1600 0838.2010.01207.x.

9. Maughan, R.J.; Shirreffs, S.M. Development of Individual Hydration Strategies for Athletes. International Journal of Sport Nutrition and Exercise Metabolism. 2008. Vol. 18, iss. 5. Pp. 457-472. DOI: 10.1123/ijsnem.18.5.457.

10. Desbrow, B.; Jansen, S.; Barrett, A.; Leveritt, M.D.; Irwin, C. Comparing the Rehydration Potential of Different Milk-Based Drinks to a Carbohydrate-Electrolyte Beverage. Applied Physiology, Nutrition, and Metabolism. 2014. Vol. 39, iss. 12. Pp. 1366-1372. DOI: 10.1139/ apnm20140174.

11. Kwiatek, M.A.; Menne, D.; Steingoetter, A.; Goetze, 0.; Forras-Kaufman, Z.; Kaufman, E., et al. Effect of Meal Volume and Calorie Load on Postprandial Gastric Function and Emptying: Studies under Physiological Conditions by Combined Fiberoptic Pressure Measurement and MRI. American Journal of Physiology Gastrointestinal and Liver Physiology. 2009. Vol. 297, iss. 5. Pp. G894-G901. DOI: https:10.1152/ajpgi.00117.2009.

12. Chen, J. Vitamins: Effect of Exercise on Requirements. Nutrition in Sport / Maugham R.M. (Ed.). Blackwell Science Ltd., 2000. Pp. 281-291. DOI: 10.1002/9780470693766.ch21.

13. Skalnyj, A.V.; Ordzhonikidze, Z.G.; Katulin, A.N. Pitanie v sporte: makro- i mikroelementy [Nutrition in Sports: Macro- and Microelements]. M.: Gorod, 2015. 144 p.

\section{Библиографический список}

1. Колесникова А.А., Артемьева Н.К., Тарасенко А.А. Динамика электролитного статуса велосипедистов высокой квалификации на фоне приема регидратационного напитка функционального назначения // Физическая культура, спорт - наука и практика. 2016. № 4. С. 73-78.

2. Savoie, F.-A.; Kenefick, R.W.; Ely, B.R.; Cheuvront, S.N.; Goulet, E.D.B. Effect of hypohydration on muscle endurance, strength, anaerobic power and capacity and vertical jumping ability: a metaanalysis. Sports Med. (Auckland, NZ). 2015. Vol. 45, iss. 8. Pp. 1207-1227. DOI: 10.1007/s4027901503490.

3. McCartney, D.; Desbrow, B.; Irwin, C. The effect of fluid intake folılowing dehydration on subsequent athletic and cognitive perfor mance: a systematic review and metaanalysis. Sports Medicine Open. 2017. Vol. 3, iss. 1. P. 13. DOI: 10.1186/s407980170079y.

4. Sawka, M.N.; Burke, L.M.; Eichner, E.R.; Maughan, R.J.; Montain, S.J. American College of Sports Medicine position stand. Exercise and fluid replacement. Medicine and Science in Sports and Exercise. 2007. Vol. 39, iss. 2. Pp. 377-390. DOI: 10.1249/mss.0b013e31802ca597.

5. Thomas, D.T.; Erdman, K.A.; Burke, L.M. Position of the academy of nutrition and dietetics, dietitians of Canada, and the American college of sports medicine: nutrition and athletic performance. Journal of the Academy of Nutrition and Dietetics. 2016. Vol. 116, iss. 3. Pp. 501-528. DOI: 10.1016/j.jand.2015.12.006.

6. McDermott, B.P.; Anderson, S.A.; Armstrong, L.E.; Casa, D.J.; Cheuvront, S.N.; Cooper, L., et al. National Athletic Trainers' Association position statement: fluid replacement for the physically active. Journal of athletic training. 2017. Vol. 52, iss. 9. Pp. 877-895. DOI: 10.4085/1062-6050-52.9.02.

7. Курашвили В.А. Проблема гидратации у элитных спортсменов // Спортивная медицина: наука и практика. 2015. № 1. С. 14-21.

8. Maughan, R.J.; Shirreffs, S.M. Dehydration and rehydration in com?petitive sport. Scandinavian Journal of Medicine and Science in Sports. 2010. Vol. 20, iss. 11, sup. 3. Pp. 40-47. D0I: 10.1111/j.16000838.2010.01207.x.

9. Maughan, R.J.; Shirreffs, S.M. Development of individual hydration strategies for athletes. International Journal of Sport Nutrition and Exercise Metabolism. 2008. Vol. 18, iss. 5. Pp. 457-472. DOI: 10.1123/ijsnem.18.5.457.

10. Desbrow, B.; Jansen, S.; Barrett, A.; Leveritt, M.D.; Irwin, C. Comparing the rehydration potential of different milk-based drinks to a car־bohydrate-electrolyte beverage. Applied Physiology, Nutrition, and Metabolism. 2014. Vol. 39, iss. 12. Pp. 1366-1372. DOI: 10.1139/ apnm20140174.

11. Kwiatek, M.A.; Menne, D.; Steingoetter, A.; Goetze, O.; Forras-Kaufman, Z.; Kaufman, E., et al. Effect of meal volume and calorie load on postprandial gastric function and emptying: studies under physi-nological conditions by combined fiberoptic pressure measurement and MRI. American Journal of Physiology Gastrointestinal and Liver Physiology. 2009. Vol. 297, iss. 5. Pp. G894-G901. DOI: https:10.1152/ajpgi.00117.2009.

12. Chen, J. Vitamins: Effect of Exercise on Requirements. Nutrition in Sport / Maugham R.M. (Ed.). Blackwell Science Ltd., 2000. Pp. 281-291. DOI: 10.1002/9780470693766.ch21.

13. Скальный А.В., Орджоникидзе 3.Г., Катулин А.Н. Питание в спорте: макро- и микроэлементы. М.: Город, 2015. 144 с.

14. Cheang, K.A. Khor. Bioceramic Powders and coatings by Thermal Spray Techniques. Proceedings of ITSC, Kobe. 1995. Pp. 181-186. 
14. Cheang, K.A. Khor. Bioceramic Powders and coatings by Thermal Spray Techniques. Proceedings of ITSC, Kobe. 1995. Pp. 181-186.

15. Klimova, E.V. Analiz Biodostupnosti Kremniya v Produktah Pitaniya (Bel'giya) [Silicon Bioavailability Analysis in Food Products (Belgium)]. Ekologicheskaya Bezopasnost' v APK. 2011. № 2. Pp. 532.

16. Vapirov, V.V.; Feoktistov, V.M.; Venskovich, A.A.; Vapirova, N.V. K Voprosu o Povedenii Kremniya v Prirode i Ego Biologicheskoj Roli [On the Silicon Issue in Nature and Its Biological Role]. Uchenye Zapiski Petrozavodskogo Gosudarstvennogo Universiteta. Obshchestvennye i Gumanitarnye Nauki. 2017. № 2 (163). Pp. 95-102.

17. Megeryan, S.D.; Maslennikova, O.M. Osobennosti Gormonal'nogo Statusa u sportsmenov vysokoj kvalifikacii [Hormonal Status Features of Highly Qualified Athletes]. Fundamental'nye issledovaniya. 2015. № 1 (Chast' 7). Pp. 1370-1373.

18. Shin, K.-A.; Park, K.D.; Ahn, J; Park, Y.; Kim, Y.-J. Comparison of Changes in Biochemical Markers for Skeletal Muscles, Hepatic Metabolism, and Renal Function after Three Types of Long-distance Running: Observational Study. Medicine (Baltimore). 2016. Vol. 95 iss. 20. P. e3657. D0l: $10.1097 / \mathrm{md} .0000000000003657$.
15. Климова Е.В. Анализ биодоступности кремния в продуктах питания (Бельгия) // Экологическая безопасность в АПК. 2011. № 2. C. 532.

16. Вапиров В.В., Феоктистов В.М., Венскович А.А, Вапирова Н.В. K вопросу о поведении кремния в природе и его биологической роли // Ученые записки Петрозаводского государственного университета. 06щественные и гуманитарные науки. 2017. № 2 (163). С. 95-102.

17. Мегерян С.Д., Масленникова 0.М. Особенности гормонального статуса у спортсменов высокой квалификации // Фундаментальные исследования. 2015. № 1 (ч. 7). С. 1370-1373.

18. Shin, K.-A.; Park, K.D.; Ahn, J; Park, Y.; Kim, Y.-J. Comparison of Changes in Biochemical Markers for Skeletal Muscles, Hepatic Metabolism, and Renal Function after Three Types of Long-distance Running: Observational Study. Medicine (Baltimore). 2016. Vol. 95, iss. 20. P. e3657. DOI: $10.1097 / \mathrm{md} .0000000000003657$.

\author{
Information about Authors / Информация 06 авторах \\ Tolmachev, \\ Vitaliy Olegovich \\ Толмачев \\ Виталий Олегович \\ Тел./Phone: +7 (343) 221-27-66 \\ E-mail: vitaly-tolmachev@bk.ru \\ Postgraduate Student \\ Ural State University of Economics \\ 620144, Russian Federation, Ekaterinburg, 8 March / Narodnoy Voli St., 62/45 \\ Аспирант \\ Уральский государственный экономический университет \\ 620144, Российская Федерация, г. Екатеринбург, ул. 8 Марта/Народной Воли, 62/45 \\ ORCID: https://orcid.org/0000-0002-3003-7192
}

\section{Tikhonov, Sergey Leonidovich}

Тихонов Сергей Леонидович

тел./Phone: +7 (343) 221-27-66 E-mail: tihonov75@bk.ru

Tikhonova, Natalya Valeryevna

тихонова Наталья Валерьевна

тел./Phone: +7 (343) 221-27-66 E-mail: tihonov75@bk.ru
Doctor of Technical Sciences, Professor, Head of the Food Engineering Department Ural State University of Economics 620144, Russian Federation, Ekaterinburg, 8 March / Narodnoy Voli St., 62/45

Доктор технических наук, профессор, заведующий кафедрой пищевой инженерии Уральский государственный экономический университет 620144, Российская Федерация, г. Екатеринбург, ул. 8 Марта/Народной Воли, 62/45 ORCID: https://orcid.org/0000-0003-4863-9834

Doctor of Technical Sciences, Professor, Professor of the Food Engineering Department Ural State University of Economics 620144, Russian Federation, Ekaterinburg, 8 March / Narodnoy Voli St., 62/45

Доктор технических наук, профессор, профессор кафедры пищевой инженерии Уральский государственный экономический университет 620144, Российская Федерация, г. Екатеринбург, ул. 8 Марта/Народной Воли, 62/45 ORCID: https://orcid.org/0000-0001-5841-1791 